\title{
MulawarmanLawReview
}

Volume 5 Issue 1, June 2020

\section{Legal Consequences of The Absense of Informed Consent in Therapeutic Transactions}

\author{
Vicia Sacharissa \\ Legal Consultant at Lubis Ganie Surowidjojo Law Firm, Indonesia. The views expressed is the author's \\ own and do not necessarily reflect the firm's opinion. \\ E-mail: vicia.sacharissa@gmail.com
}

\begin{abstract}
A person's right to their own body is one of the human rights protected under the right to selfdetermination, 1 and this protection also applies to patients seeking treatments. The process of giving information by the doctor, which is then followed with the consent to medical action by patient, is known as informed consent. In Indonesia, the protection of such right is contained in various laws and regulations. This is a descriptive legal research, with normative-judicial or library research method and qualitative data analysis. The discussion covers topics regarding therapeutic transaction as a form of agreement, the presence of informed consent in therapeutic transactions, and the consequence of the absence of informed consent from the perspective of civil law. It is also supplemented with case decision study on Case Decision No. 3203 K/Pdt/2017 which proves that the lack of informed consent is a legitimate ground for a lawsuit.
\end{abstract}

Keywords: Informed Consent; Informed Refusal; Patient Rights; Therapeutic Transactions.

Citation: Sacharissa, Vicia. 2020. "Legal Consequences of The Absense of Informed Consent in Therapeutic Transactions". Mulawarman Law Review 5 (1), 1-17. https://doi.org/10.30872/mulrev.v5i1.296.

\section{INTRODUCTION}

In the past, relationship between the provider of health services (doctors and medical staff) and the recipient of such health services (patients) were not one of equal standing. The providers of health services were considered to know better than the patients, giving way to a paternalistic and biased relationship - also where the term 'father knows best' started to be used in a medical context, describing how doctors and medical staffs were thought to know what's best for their patients. The pattern of a paternalistic relationship is identical to a vertical one, and in medical context, the patient is considered to know next to nothing about their illness and surrender their fate entirely to the health service provider. ${ }^{1}$

${ }^{1}$ Hermien Hadijati Koeswadji. (1998). Hukum Kedokteran: Studi tentang Hubungan Hukum dalam mana Dokter sebagai Salah Satu Pihak. Bandung: Citra Aditya Bakti. p. 37. 
Along with the development of knowledge and awareness of patients' rights, there was a shift of paradigm in the way people perceive the relationship between patients and providers of healthcare services. Patients began to demand reciprocal relationship with providers of healthcare services based on mutual respect of their respective rights and obligations. ${ }^{2}$ If the previous paternalistic relationship between providers of healthcare services and patients was identical to the pattern of vertical relationships, now it is closer to the pattern of horizontal contractual relationship, in which both sides have equal position. ${ }^{3}$

In the pattern of a contractual horizontal relationship, each party is considered to have the same knowledge about the patient's condition, the illness they are suffering from and the ways of healing, so that if one party feels unsatisfied or unsuitable with the implementation of the agreement, they have the right to cancel the agreement. ${ }^{4}$ In the Law of Agreement, this relationship is essentially a sale-purchase relationship that is identical to the relationship between producers and consumers: patients as the consumer of health services, and doctors or medical staff as the seller of health services. ${ }^{5}$ This kind of contract is known as a therapeutic agreement or therapeutic transaction.

Since in a therapeutic transaction doctors and patients are of equal position, the two parties cooperate to find the most appropriate therapy to treat the patient's illness. In medical science, a patient is no longer seen as a mere object, but a subject with an equal standing to the doctor, with rights and obligations that shall be respected as much as the doctor's. Therefore, as a subject of the agreement who has power over their own body, the patient must get sufficient information about the actions that will be done to their body, and by extension have the power to decide whether to approve of decline such action. Consent based on sufficient information from doctors and medical staff regarding the disease, alternative treatment efforts, and consequences that may arise from the treatment efforts is known as informed consent. ${ }^{6}$

Therapeutic transactions, like general contracts and agreements, are subject to general provisions of Contractual Law, as set out in Book III of the Indonesian Civil Code ("Civil Code"). As an agreement, therapeutic transactions have two parties: the doctor or medical staff as the provider of medical services and the patient as recipient of such medical services. Since this transaction is a consensual, mutual relationship, there are rights and obligations that each party must fulfil. The existence of informed consent itself is one of the patient's rights, in which they are free to accept or decline any treatment to be carried out on their body. As a right arising from agreement, the patient's right for informed consent is protected under the civil law.

${ }^{2}$ Anny Isfandyarie. (2006). Tanggung Jawab Hukum dan Sanksi bagi Dokter. Jakarta: Prestasi Pustaka. p. 90.

${ }^{3}$ Hermien Hadiati Koeswadji. Op. cit. p. 46.

${ }^{4}$ Anny Isfandyarie. Op. cit. p. 94.

${ }^{5}$ Ibid.

${ }^{6}$ Veronica Komalawati. (1989). Hukum dan Etika dalam Praktik Dokter. Jakarta: Pustaka Sinar Harapan. p. $84-86$ 


\section{METHOD}

This paper is a descriptive legal research which aims to obtain a complete description or narrative regarding the state of law in force in a particular place at a certain timeframe, or the juridical symptoms that exists or certain legal events that occur in a specified general public. On the other hand, the method used in obtaining the data is the juridicalnormative legal research method, synonymous with library research. The juridicalnormative approach refers to the legal norms contained in legislations, preceding researches, and various forms of literature.

The data analysis used in this study was a qualitative analysis, which resulted in a descriptive data in order to obtain a complete image regarding certain topic according to the researcher. ${ }^{7}$ Qualitative research emphasizes inductive analysis, in contrast to deductive analysis. The data collected is not intended to support or reject certain hypothesis prepared before the research begins, but to elaborate and narrow down the abstractions that have been collected and grouped together through a careful process of data collection. In this study, researchers develop concepts and collect facts, but do not test existing hypothesis through the calculation of numbers. ${ }^{8}$

\section{ANALYSIS AND DISCUSSION}

\section{A Legal Reviews of Therapeutic Transactions}

The term 'therapeutic' means treatment in itself. The therapeutic transaction was first put forward by Hippocrates, which provided a rational basis for relationship between a doctor and their patient. In this context, doctors are not regarded as someone who knows everything, rather as ordinary people who became 'sacred' after taking the Hippocratic Oath at the end of their education. ${ }^{9}$

Therapeutic transactions are defined as agreements between doctors and/or medical staff and patients, in the form of a legal relationship that resulting in rights and obligations for both parties. ${ }^{10}$ Hermien Hadiati Koeswati defined therapeutic transactions as an agreement made between a doctor and a patient to seek or find therapy as an effort to cure the patient's disease by the doctor. ${ }^{11}$ Amri Amir described therapeutic transactions verbatim: transactions or agreements or contracts are interpreted as a consensual, reciprocal relationship between two parties on a certain matter, whereas therapeutic, referring to its English definition, is interpreted as 'in the field of treatment', instead of translated as therapy or treatment. This is because the agreement that occurs between the doctor and the patient is not limited to the field of medicine but is broader, covering the diagnostic, preventive, rehabilitative and promotive fields as well, so the term 'therapeutic agreement' is considered more

\footnotetext{
${ }^{7}$ Sulistyo Basuki. (2010). Metode Penelitian. Jakarta: Penaku. p. 78

${ }^{8}$ Andi Prastowo. (2012). Metode Penelitian Kualitatif Dalam Perspektif Rancangan Penelitian. Yogyakarta: Ar-ruzzmedia. p. 45.

${ }^{9}$ Hermien Hadiati Koeswadji. Op. cit. p. 24

${ }^{10}$ Bahder Johan Nasution. (2005). Hukum Kesehatan - Pertanggungjawaban Dokter. Jakarta: PT. Rineka Cipta. p. 11.

${ }^{11}$ Hermien Hadiati Koeswadji. Op. cit. p. 26.
} 
accurate. ${ }^{12}$ Meanwhile, Veronica Kumalawati stated that a therapeutic agreement is a legal relationship between doctors and patients in a professional medical service based on competencies that are in accordance with certain expertise and skills in the medical field. ${ }^{13}$

The definitions of therapeutic transactions from Bahder Johan Nasution, Hermien Hadiati Koeswadji and Veronica Komalawati have a similar weakness, namely a narrow definition. All three of them define therapeutic transaction as agreements between doctors and patients, but in reality, other medical staff and health workers such as nurses and midwives are also liable to form a therapeutic agreement with patients.

Therapeutic transactions are not regulated in any specific part of the Civil Code, but according to the provisions of Article 1319 of the Civil Code, all agreements, both nominaat and innominaat, are subject to contractual bond in general (Chapter I Book III of the Civil Code) and agreements (Chapter II Book III of the Civil Code). And if the term 'transaction' or 'agreement'14 is put into context with the civil law, then the parties who enter the agreement must satisfy the conditions stated in Article 1320 of the Civil Code, namely:

a. There must be consent of the individuals who are bound thereby (toestemming van degene die zich verbinden): in a therapeutic transaction, the agreement begins with a statement of will and mutual exchange of information between the parties to be involved. ${ }^{15}$

b. There must be capacity to conclude an agreement (bekwaamheid om eene verbintenis aan teaan): this requirement must be met by both the patient as the party requesting the service, and by the doctor as the party providing the service. The patient must be someone declared competent by law, that is, a sane adult, and if the they are immature or insane then someone competent must be present to accompany them. The same thing applies to doctors and medical staff, with the addition that physicians must have the necessary skill to aid the patient. The skills can be proven with a diploma or a certificate recognized by the Government and the relevant board of experts. ${ }^{16}$

c. There must be a specific subject (een bepaald onderwerp): in therapeutic transactions, the subject is one or more diseases or conditions that need to be addressed by the doctors or medical staff. ${ }^{17}$

d. There must be an admissible cause (geoorloofde oorzaak): an admissible cause refers to a cause that does not violate the law. For example, in case of therapeutic transactions, inadmissible causes would be things like illegal

12 M. Jusuf Hanafiah and Amri Amir. (1999). Etika Kedokteran \& Hukum Kesehatan: Edisi 3. Jakarta: Penerbit Buku Kedokteran EGC. p. 39.

${ }^{13}$ Veronika Komalawati. (1999). Peranan Informed Consent dalam Transaksi Terapeutik: Suatu Tinjauan Yuridis Persetujuan dalam Hubungan Dokter dan Pasien. Bandung: Citra Aditya Bakti. p. 1.

${ }^{14}$ Hermien Hadiati Koeswadji. Loc. cit.

${ }^{15}$ M. Jusuf Hanafiah and Amri Amir. Op. cit. p. 41

${ }^{16}$ Bahder Johan Nasution. Op. cit. p. 12

17 Ibid. 
abortion, plastic surgery to avoid being arrested by the police, or fingerprint removal surgery. ${ }^{18}$

Wirjono Prodjodikoro stated that in a legal relationship, there are objects, subjects, and causa which are described as follows: ${ }^{19}$ (a) The object in a legal relationship is a certain matter that the parties agreed upon; (b) The subject in a legal relationship is a person or a legal entity that is under the burden of an obligation in exchange for a right of something; (c) The causa in legal relationship is the thing that causes such legal relationship to exist in first place, namely a series of interests that must be maintained and taken into consideration in the legal relationship.

Based on the description above, when referring to the legislation in the health sector, the legal relationships that occur in therapeutic transactions are as follows: ${ }^{20}$ (a) The legal object of a therapeutic transaction is the obligation that must be carried out by the doctor to patients who are entitled to receive medical treatment or efforts, where the therapeutic transaction is considered as a transaction to find or determine the most appropriate therapeutic effort for the patient. So, according to the law, the object of therapeutic transactions is not the patient's healing but instead the effort to find the right cure for the patient; ${ }^{21}$ (b) The legal subject of a therapeutic transaction is the doctor on one hand, carrying out or providing health services, and the patient on the other, as recipient of such health services; and (c) The causa of a therapeutic transaction is an effort to realize the optimal health status for the community through maintenance, health promotion (promotive), disease prevention (preventive), healing (curative), and health recovery (rehabilitative) activities that are carried out in a continuous, integrated manner.

Compared to agreements in general, there are certain distinctions in therapeutic transactions, namely in terms of: (a) How to pledge therapeutic transactions: when the patient comes to the doctor's office or the place where the doctor works for the purpose of checking his health or for treatment, then at that time the therapeutic transaction is considered to have occurred; ${ }^{22}$ (b) In medical measures, there is informed consent as the patient's unilateral right to approve what actions may or may not be done on his body. The consent can be revoked at any given time before the agreed medical procedure is implemented; and (c) The outcome of the medical service agreement is uncertain. ${ }^{23}$

In civil law, there are two types of agreements, namely resultaatververbintenis (agreements based on results) and inspanningverbintenis (agreements based on maximum effort). There are two different opinions regarding which agreement a therapeutic transaction is categorized as.

18 Ibid.

19 Y.A. Triana Ohoiwutun. (2009). Bunga Rampai Hukum Kedokteran, Cetakan Kedua. Malang: Banyumedia Publishing. p. 9

${ }^{20} \mathrm{lbid}$

${ }^{21}$ Bahder Johan Nasution. Op. cit. p. 11.

22 lbid, p. 12.

${ }^{23}$ Y. A. Triana Ohoiwutun. Op. cit. p. 12 
The first opinion is that generally, therapeutic transactions are categorized as inspanningverbintenis, but transactions pertaining to certain procedures are categorized as resultaatververbintenis. In this case, doctors and medical staff carefully use their knowledge, intelligence, skills and experience to cure patients. The results of the doctor's efforts are uncertain: there is a possibility that the patient will recover, remain ill, become sicker, or even die. Doctors cannot guarantee the results of their efforts in providing health services. ${ }^{24}$ However, there are therapeutic transactions that emphasize results, for example agreements made by doctors with patients in the manufacture of dentures or fabrication of prosthetic organs. ${ }^{25}$

The second opinion is that all therapeutic transactions fall into the category of inspanningverbintenis, since a doctor is only obliged to perform health services in maximum effort by using all their skills and abilities according to the professional standards. ${ }^{26} \mathrm{~A}$ doctor isn't obliged to produce an exact, certain result as required by resultaatververbintenis agreements, only to provide attention, accuracy, expertise, and tenacity for the patient's interests. ${ }^{27}$

\section{Informed Consent in Therapeutic Transactions}

Therapeutic transaction is an interaction between a doctor or medical staff with the patient in order to find the most appropriate recovery efforts to cure the illness of the patient, and this interaction leads to a relationship known as a doctor-patient relationship. Informed consent also covers regulations governing the interaction between a physician and their patient.

The term informed consent consists of the words 'informed' and 'consent'. 'Informed' is defined as having received an explanation or information; whereas consent means giving consent or allowing. Thus informed consent can be interpreted as an approval given after receiving information. ${ }^{28}$ It can also be interpreted as a statement of agreement from patients, which are given on their own accord, freely and rationally, after getting and understanding the necessary information from the doctor. ${ }^{29}$ With the patient aware of what medical procedures and treatments the doctor will carry out, they can opt out of the medical treatment if they wanted to. Hermien Hadiati stated that in essence, informed consent is an exercise of the right to health care and the right of self-determination, both important rights of the patients that must be acknowledged and respected.

According to the Indonesian Medical Council (Konsil Kedokteran Indonesia, "KKI"), informed consent is an Approval of Medical or Dental Measures, a consent given by the patient or their legitimate representative over a medical or dental treatment plan

\footnotetext{
${ }^{24}$ Ibid, p. 11.

25 Ibid.

${ }^{26}$ Bahder Johan Nasution. Op. cit. p. 13

27 Ibid, p. 15

${ }^{28}$ Husein Kerbala. (2000). Segi-Segi Etis dan Yuridis Informed Consent. Jakarta: Pustaka Sinar

29 J. Guwandi. (2006). Informed Consent \& Informed Refusal. Jakarta: Fakultas Kedokteran
} Harapan. p. 57. Universitas Indonesia. p. 1. 
filed by a doctor or dentist, after receiving enough information to approve such plan. ${ }^{30}$ The approval of such medical or dental treatment is a one-sided statement from the patient, and not an agreement between the patient and doctor or dentist, so it can be withdrawn at any given time. Informed consent includes the process of giving the information as well as the result of effective communication between the parties, not just the signing of the consent form. A consent is considered valid if: ${ }^{31}$ (a) The patient has been given sufficient explanation or information; (b) The patient or their legitimate representative is considered competent to make a decision or give approval; and (c)The approval must be given voluntarily.

Law No. 36 of 2009 on Health ("Health Law") does not provide any definite definition of informed consent, but alludes to informed consent in several articles. Article 8 of Health Law states that every person has the right to obtain information regarding their medical data, including actions and treatments that they will or have received from the medical staff. Furthermore, Article 56 paragraph (1) states that everyone has the right to accept or decline part or all of the relief measures that will be given to them after receiving and understanding information about such actions in full.

The most relevant regulation pertaining to this matter is the Regulation of the Minister of Health No. 290/MENKES/PER/III/2008 on the Approval of Medical Action (the Indonesian term of informed consent, and hereinafter the term 'informed consent' will be used instead, and this regulation will be referred to as the "Informed Consent Regulation"). In Article 1 figure 1 it is stated that the approval of medical action is an approval given by the patient or their immediate family after obtaining a complete explanation about the medical or dental procedure that will be carried out towards the patient. Article 1 figure 2 then defines immediate family as a spouse, parent, sibling or facilitator.

Informed consent can be given verbally or in writing, but Law No. 29 of 2004 on Medical Practices ("Law on Medical Practices") requires written approval from the patient for highrisk procedures. In practice, if the patient is unconscious or in other conditions that make it impossible for them to sign the consent form, then their parents, spouse, family member, or anyone that escorts them can sign the form on their behalf. The substance of the consent is a medical procedure or health service that will be performed by the doctor as a form of health service. ${ }^{32}$

Consent given by the patient is limited - meaning that the doctor may only carry out medical procedures that have been approved by the patient. Thus, according to the $a$ contrario interpretation, doctors are prohibited from carrying out extended procedures like additional surgery or other medical procedures that have not been approved by the patient. However, Regulation on Informed Consent provides certain conditions in which such extension surgery is allowed, namely: (1) Unpredictable

30 Konsil Kedokteran Indonesia. (2006). Manual Persetujuan Tindakan Kedokteran. Jakarta: Konsil Kedokteran Indonesia. p. 1.

${ }^{31}$ Adriana Pakendek. (2010). “Informed Consent Dalam Pelayanan Kesehatan”. Jurnal Al-Ihram Universitas Madura Pamekasan, Vol. 5(2): 312.

32 Alexandra Indriyanti Dewi. (2008). Etika dan Hukum Kesehatan. Yogyakarta: Penerbit Pustaka. p. 26. 
extension surgery; (2) Extension surgery intended to save the patient's life; (3) When the patient is unconscious and/or not escorted by their family; (4) The extension surgery is of an emergency nature.

Although the patient's consent is limited, does not mean the doctor must always seek the patient's approval for other actions related to the operation. The doctor is considered to have obtained the consent of the patient to carry out other actions related to the operation, a concept known as implied consent - for example, premedication or shaving of the hair on the part of the patient's body to be operated on. ${ }^{33}$ Doctors also don't need to obtain approval to act on emergency patients, especially if they aren't accompanied by a family member. As a basis for this action, Leenen suggests a juridische fictie (legal fiction) that a person in an unconscious state will approve what is generally agreed upon by patients who are conscious and in the same condition. Fred Ameln called this a presumed consent, while van der Mijn linked this to Article 1354 of the Civil Code governing zaakwarneming (voluntary representation). Doctors are considered zaakwarneming who perform medical actions to save the lives of patients. ${ }^{34}$

In this regard, there are two forms of informed consent. The first type is expressed informed consent, which can be given verbally or in writing; and the second one is implied informed consent which is given under normal circumstances or in emergency situations.

Expressed consent is a consent that may be expressed verbally or in writing, if what is to be done is more than the usual inspection procedures and actions. Patients should be given an understanding in advance regarding what actions will be performed. For example, examination in the anus or rectum or examination in the vagina, or others that exceed the general examination procedures and measures. In this case a written statement is not yet needed, an a verbal approval may be enough. However, if the action carries a high risk, such as surgery or invasive examination and treatment procedures, then the consent must be given in writing.

Implied consent is a consent given by the patient implicitly, without explicit statement. This consent is alluded by the doctor from the patient's attitude when the doctor takes action, for example in taking blood for laboratory tests, giving injections to the patient, suturing the wound and so on. Implied consent applies to actions that are commonly carried out or are well known to the public.

Sudikno Mertokusumo stated that patients can give informed consent with, among others: $^{35}$ (a) In perfect, written language; (b) With verbally perfect language; (c) With imperfect language, as long as it is acceptable to the other party; (d) In sign language, as long as it is acceptable to the other party; (e) Silently or in silence as long as it is understood by the other party.

\footnotetext{
${ }^{33}$ Husein Kerbala. Op. cit. p. $85-86$.

${ }^{34}$ Alexandra Indriyanti Dewi. Op. cit. p. 86.

${ }^{35}$ Anny Isfandyarie. (2005). Malpraktek dan Resiko Medik dalam Kajian Hukum Pidana. Jakarta: Prestasi Pustaka Publisher. p. 58..
} 
The Indonesian Doctors Association (Ikatan Dokter Indonesia, "IDI") released a statement regarding the conveyance of informed consent as published in IDI Decree No. 319/PB/A4/88 as described below: (1) A physically and mentally healthy adult has the right to fully determine what they want to do to their own body. The doctor is not entitled to take medical actions that are contrary to the wishes of the patient, even if it's for the patient's own benefit; (2) All medical procedures (diagnostic, therapeutic or palliative) require verbal or written informed consent; (3) Every medical action that has a substantial risk requires a written agreement signed by the patient, after the patient receives adequate information about the necessity for such medical action and the relevant risks; (4) For actions that are not included in point 3, only verbal approval or silence is required; (5) Information about medical measures must be given to patients, whether it is requested and not requested by patients. Withholding information is forbidden, unless the doctor considers that the information may be detrimental to the patient's health interests. In this case the doctor can provide information to the patient's immediate family. In providing information to the immediate family of the patient, the presence of another nurse or paramedic as a witness is important. (6) The contents of the information include the advantages and disadvantages of the planned medical actions, whether diagnostic, therapeutic or palliative. Information is usually given verbally, but it can also be in writing (relating to informed consent).

Because the patient's approval is definitely required, it has become a necessity for doctors or health facilities to always keep evidence of informed consent. Medical record files generally provide one sheet as an informed consent sheet. The signing of written informed consent by the patient before any medical action is taken is done at health facilities such as hospitals or clinics because it is closely related to documentation in the medical record. Hospitals are partly responsible if the requirements of informed consent was not fulfilled, and the doctor may be subject to administrative sanctions. ${ }^{36}$

Informed consent is only considered valid when the patient has obtained clear information about the medical actions that will be carried out on their body. In providing this information, the doctor is obliged to disclose and explain to patients in the simplest language possible about the nature of the disease, the nature of the recommended treatment, alternative treatments, the likelihood of success and the risks that can arise as well as irreversible complications.

Even though it is only a piece of paper, the signed informed consent sheet can be used as evidence in court in the event of a future lawsuit. In connection with that, one of the methods used to protect the interests of doctors against patient demands is by explicitly stating in the consent form that the doctors will not be prosecuted in the future: if the patient is fully aware of all the risks of the medical action to be performed by the doctor, and something unexpected happens during the medical procedures, then the patient will not make file any lawsuit to the court in the future. ${ }^{37}$

\footnotetext{
${ }^{36}$ Veronika Komalawati. Op. cit. p. 180

37 Ibid, p. 72
} 
Patients may refuse to give consent after being given an explanation through informed consent, and the such refusal is known as informed refusal. This can be justified based on a person's basic rights to determine what may and may not be done upon their body. For informed refusal, the patient must understand all the consequences that may arise due to the rejection and that the doctor cannot be blamed for it, and sign the Medical Action Refusal form. The refusal can occur due to many things, like the inability to pay or the patient's fear of such medical action. In response to patients who refuse such medical measures, doctors must not and do not have the right to impose. They must respect the patient's right to self-determination, even though the reason for the refusal might sound absurd or strange.

The Consequence of the Absence of Informed Consent from the Perspective of Civil Law

Informed consent is a part of the field of Medical Law, as a branch of Legal Studies, and that means Medical Law must also follow systematic Legal Studies in general. ${ }^{38}$ There are three common types of sanctions, namely administrative sanctions, civil sanctions (usually in the form of compensation), and criminal sanctions (corporate law; fines). In addition, there are sanctions in the field of Ethics and Discipline which includes the authority of professional organizations that the law does not interfere with. This article will discuss informed consent from the perspective of civil law.

The civil law is identical to agreement. Based on the discussion above, in the context of informed consent, therapeutic transaction as one of the agreements subjected to the Civil Code is the closest thing we have to an agreement. In practice, therapeutic transactions are often equated with informed consent, but it shall be highlighted that the two are different things. Therapeutic transactions are relationships or interactions between doctors and patients, while informed consent is something that needs to be fulfilled arising from that relationship. Therapeutic transactions are not the same as informed consent. ${ }^{39}$

From the perspective of civil law, informed consent is a toestemming (a unilateral aprroval or permission) given by the patient to the physician who will carry out a medical action on him, and the approval was based on sufficient information that they have received. Thus, unlike an agreement, this consent can be revoked by the patient at any given time. ${ }^{40}$ Therefore, informed consent is only one of the conditions for the occurrence of therapeutic transactions which must be distinguished from the legal conditions of the agreement, as stipulated in Article 1320 of the Civil Code.

However, between the conditions of occurrence and the legal requirements for therapeutic transactions, there are very close similarities, namely: ${ }^{41}$ (1) For a therapeutic transaction to occur, there must be consent from the patient to the doctor who will carry out medical actions. Patient's consent must be based on sufficient

\footnotetext{
${ }^{38}$ Konsil Kedokteran Indonesia. Op. cit. p. 3

${ }^{39}$ Husein Kerbala. Op. cit. p. 84.

40 Ibid.

41 lbid.
} 
information, which can be used as a guideline or basis for consent. (2) If the patient has given consent to the doctor, in order for the consent to be valid, it still has to fulfil the conditions stated in Article 1320 of the Civil Code.

The absence of informed consent from the perspective of civil law can be seen from three sides: (1) The absence of informed consent which results in not fulfilling one of the conditions of the agreement according to Article 1320 of the Civil Code; (2) The absence of informed consent that is categorized as default or breach of contract (wanprestasi); and (3) The absence of informed consent that is classified as tort under Article 1365 of the Civil Code.

First, the absence of informed consent which results in not meeting one of the conditions of an agreement as stated in Article 1320 of the Civil Code. Chapter 2 has explained the legal aspects of therapeutic transactions as a form of engagement, including the fulfillment of the terms of the agreement as stated in Article 1320 of the Civil Code.

If the requirements were to be elaborated further and associated with informed consent, then the following points can be taken: (a) The consent of the individuals who are bound thereby (toestemming van degene die zich verbinden): a mutual exchange of information between the parties that will be involved is outlined in the form of informed consent. With the existence of informed consent, it means that the patient or their representative and the doctor or medical staff have agreed to do and/or not do something; (b) The capacity to conclude an agreement (bekwaamheid om eene verbintenis aan te gaan): this is about the patient's ability to give consent or the capacity to act, in which incompetent patients who are not qualified to consent can be represented by their guardian, spouse, parents, adult siblings, adult offspring or a party that has been given a power of attorney. Whereas doctors and health workers must have the skills needed by patients, which can be proven with relevant certificates or letters; (c) A specific subject (een bepaald onderwerp): meaning that informed consent raises rights and obligations that need to be fulfilled by each party. Such rights and obligations must be present, and it is also related to legal action that can be taken in the event of a dispute - with the existence of rights and obligations, the injured party can sue on the grounds that the opponent failed to carry out their obligations; (d) An admissible cause (geoorloofde oorzaak): that informed consent is not given for things that violate the law, such as illegal abortion.

The non-fulfillment of conditions a and $b$ causes a therapeutic transaction to be liable for cancellation, while the non-fulfillment of conditions $c$ and $d$ causes the therapeutic transaction to be null and void.

Second, the absence of informed consent that is classified as breach of contract or default. Defaults can be classified into four forms: ${ }^{42}$

1. The non-fulfilment of obligation: for example, in a therapeutic transaction, the patient and doctor have agreed on the removal of cysts at two points on the patient's body. But in the end only one cyst was removed, contrary to what has

${ }^{42}$ Subekti. (1987). Hukum Perjanjian. Cetakan XI. Jakarta: PT Intermasa. p. 4. 
been agreed before. This is detrimental to the patient's interests, and in this case, it is considered to be a breach of contract.

2. The incorrect fulfilment of obligation: for example, the patient and doctor have agreed to carry out an appendicitis surgery with the most up-to-date methods that will not require any major surgery. But in the end, the removal of appendicitis is done with a conventional surgery, contradicting the patient's consent and is detrimental for the patient. In this case, it is considered to be a breach of contract as well.

3. The late fulfilment of obligations: for example, the patient and doctor have agreed to operate on a specific day and time, but on the t-day, when the patient is ready, the doctor arrives late instead, resulting in the postponement of surgery, and it is detrimental to the patient's interests. In this case, it is considered to be a breach of contract.

4. Doing what should not have been done: for example, the patient gives consent to take certain types of drugs and refuses other types of drugs that will be prescribed by the doctor. However, doctors still write drugs that are rejected by the patient, which results in unwanted side effects by the patient. It is considered to be a breach of contract as well.

In the event of breach of contract or default, the solution that can be provided is in the form of: (a) Fulfilment of agreement; (b) Fulfillment of the agreement followed with compensation; (c) Payment of compensation only; (d) Cancellation of the agreement; or; (e) Cancellation of agreement followed with compensation.

Third, the absence of informed consent which is classified as tort or onrechtmatigedaad in accordance with Article 1365 of the Civil Code. This article states that any party who commits an illegal act which causes damage to another party shall be obliged to compensate therefor. To file a lawsuit based on acts against the law, in the context of a therapeutic transaction, it is necessary to fulfill the conditions contained in Article 1365 of the Civil Code, namely: (a) The patient must suffer from a loss; (b) A mistake must have occurred; (c) There is a causal relationship between the mistakes and the losses; (d) The act committed violates the law.

If the above theory is applied to the relationships that occur in the absence of informed consent, then the patient must be able to prove the following: ${ }^{43}$ (1) That the loss or damage suffered by the patient is a result of medical actions taken by the doctor against their wish; (2) Whereas if informed consent is fulfilled, it is likely that the patient will choose other alternatives that are more beneficial to them, so that in the absence of informed consent, the loss suffered by the patient is greater than if the informed consent was fulfilled; (3) That if the patient is given the opportunity to determine their choice in the actions the doctor is about to take, objectively anyone who is a patient may make the same choice as that patient. In other words, the patient's reason for choosing the alternative makes sense from an objective point of view in a causal relationship; and (4) If the information provided to the patient is clear

${ }^{43}$ Bahder Johan Nasution. Op. cit. p. 70. 
enough, the patient may make the decision to choose other medical measures from the perspective of subjective standards in causal relationships.

Before the patient files a lawsuit due to the absence of informed consent, there are requirements that must be fulfilled. The juridical elements that must be met in this case are: ${ }^{44}$ (1) There is an obligation for the doctor to give informed consent; (2) Such obligation is not carried out without juridical justification; (3) There is a loss or damage on the part of the patient; and (4) There is a causal relationship between the absence of informed consent and the loss incurred.

A well-known case in Indonesian history relating to informed consent is the Sukabumi District Court Decision No. 40/Pdt.G/1986, also known as the Muhidin Case. The father of Muhidin Sukendar filed a lawsuit against an ophthalmologist after he removed his son's eyeballs without his permission as the person authorized to give informed consent on behalf of Muhidin. Unfortunately, the Sukabumi District Court ruled that this lawsuit was not acceptable, because Muhidin's father filed the lawsuit against the ophthalmologist personally. The legal considerations stated that because the doctor works at the hospital, and at the time of the incident the doctor was doing his duties under the hospital, then all consequences arising could not be borne by the doctor personally, and the lawsuit should have been addressed to the hospital instead. In the end, Muhidin and his father did not make further legal efforts, but this case underlies the birth of the Indonesian Doctors Association Decree on Informed Consent through Decree PB-IDI No. 319/PB/A.4/88 in 1988.

It can be concluded that the absence of informed consent has the potential to cause problems only if the doctor's actions caused harm to the patient. Doctors may be subject to criminal prosecution or tort if an intervention without the patient's consent causes injury or pain that makes the patient suffer a loss or disruption in daily life, for example in the form of: ${ }^{45}$ (1) Physical disability or serious injury; (2) Material losses (costs incurred); (3) Loss due to pain; (4) The loss of employment opportunities due to pain; (5) Action against a patient's beliefs and religion; or (6) The patient passed away.

\section{Case Study of Decision No. 3203 K/Pdt/2017}

One of the court decisions regarding informed consent is the Decision of the Supreme Court of the Republic of Indonesia Number $3203 \mathrm{~K} / \mathrm{Pdt} / 2017$. The case in this ruling is the installation of dental implants that were not carried out without sufficient information given to the patient and were not in accordance with applicable medical procedures, and were classified as unlawful.

Samat Ngadimin (the "Plaintiff") is a patient of Drg. Yus Andjojo D.H. (the "Defendant"), a dentist who opened a clinic in Jakarta. On the recommendation of one of his friends, the Plaintiff visited the Defendant for treatment as well as dental implants. After he underwent four dental implant surgery operations with the Defendant, he felt that the disease he was suffering from was getting worse instead,

${ }^{44}$ Ibid, p. 161 - 162

${ }^{45}$ Munir Fuady. Op. cit. p. 69. 
and he was also suffering with the pain and trauma experienced due to multiple surgeries.

When Plaintiff conveyed his concern to the Defendant, he still forced the Plaintiff to undergo another dental implant surgery on the grounds that the doctor had been practicing a new dental implant technique he just learned for one week in Italy. Two days after the fifth implant operation, the Plaintiff realized that his gum had been reeking a foul smell. Worried and concerned, he returned to the Defendant to ask for help and demand accountability, but instead was asked to return again within two days. The next day the Plaintiff returned to the clinic and insisted that the dentist should check his gums, but the Defendant refused based on experience with his previous patients.

In the end, the Defendant agreed to disassemble the dental implant. However, it was found that the Plaintiff's gums had become rotten, and the Defendant turned out to have performed medical treatment without the approval of the Plaintiff, which was to put implants on other teeth, causing them to decompose and had to be removed.

Other informed consent violations committed by the Defendant was when he did not respect the Plaintiff's reluctance to carry out another surgery for the nth time. The Plaintiff conveyed his trauma of surgery, but the Defendant insisted on operating the Plaintiff without providing options for alternative treatment or even stopping the treatment altogether. Based on consultations with other dentists, the Plaintiff was informed that his initial illness could have been cured without major surgery as suggested by the Defendant.

In the Health Law, despite not mentioning informed consent explicitly, there are several articles that regulate the protection of informed consent. First, in Chapter Two, the Second Paragraph on Patient Protection, specifically Article 56, which states that:

1. Everyone has the right to accept or reject part or all of the relief measures that will be given to them after receiving and understanding information about such actions in full.

2. The right to accept or reject such action as referred to in paragraph (1) does not apply to: (a) People suffering from diseases which can be transmitted quickly to the wider community; (b) Someone who is unconscious; or (c) People with severe mental disorder.

3. Provisions regarding the right to accept or reject such action as referred to in paragraph (1) are further regulated in accordance with the provisions of the other relevant legislation.

Article 56 of the Health Law laid the basis for general informed consent in Indonesia. In the explanation, no further elaboration was found because Article 56 was deemed sufficiently clear. Article 56 also acknowledges the right of a person to refuse medical action or informed refusal. This is also supported by Article 45 paragraphs (1) through (3) of Law on Medical Practices which states that:

(1) Every medical or dental action that will be performed by a doctor or dentist on a patient must first obtain approval. 
(2) Approval as referred to in paragraph (1) is given after the patient gets a complete explanation.

(3) The explanation referred to in paragraph (2) shall at least cover: (a) the diagnosis and procedure for medical treatment; (b) the purpose of the medical treatment; (c) other alternative actions and risks; (d) risks and complications that might occur; and e. prognosis of the actions taken.

Informed consent is also regulated in Law No. 36 of 2014 on Health Workers ("Law on Health Workers"). Article 58 paragraph (1) letter b requires health workers to obtain consent from the patient or family before carrying out any medical actions or treatment on the patient's body.

The right to accept or refuse medical treatment is now regulated further in the Informed Consent Regulation which, in its entirety, regulates the formal aspects of informed consent, i.e. the procedure for granting approval and rejection of medical action; who has the right to give consent and rejection of medical measures; responsibilities; and procedures to obtain informed consent. According to Article 7 paragraph (3) jo. Article 8 paragraph (1) to (4) of the Informed Consent Regulation, information that must be given by a doctor to a patient at least includes: (1) Diagnosis and procedure of medical treatment; (2) The purpose of the medical action to be taken; (3) Other alternative actions and risks; (4) Possible risks and complications; (4) Prognosis for actions taken; and (5) Estimated cost.

Based on the existing regulations, the series of surgery done by the Defendant and the installation of implants in other teeth that were not done in accordance with the patient's consent, according to the Plaintiff's statement that was not denied by the Defendant, showed the absence of informed consent from the patient. Judex Juris believed that the surgery and dental implant both carry high risks of failure, thus the actions of the Defendant who performed several dental implantation surgeries without the knowledge of the Plaintiff, was a clear violation against the law.

\section{CONCLUSION}

Therapeutic transaction is a relationship between doctors or medical staff as providers of health services and patients as recipients of health services, and is subject to the terms of general agreements in the Civil Code. Meanwhile, informed consent is a toestemming or unilateral approval or permission, given by the patient to the doctor or medical staff to perform certain medical actions, which can be revoked any time, and is one of the conditions for a therapeutic transaction to occur, and shall be distinguished from other requirements for agreement.

According to the civil law, the absence of informed consent can be categorized into three types. The first is the absence of informed consent which results in not fulfilling one of the conditions of the agreement according to Article 1320 of the Civil Code; the second is he absence of informed consent that is categorized as default or breach of contract (wanprestasi); and the third is the absence of informed consent that is classified as tort under Article 1365 of the Civil Code. 
Since therapeutic transactions are a form of agreement, patients are entitled to receive compensation due to loss suffered from the absence of informed consent. In such event of loss, compensation can be provided in the form of: (a) Fulfilment of agreement; (b) Fulfillment of the agreement followed with compensation; (c) Payment of compensation only; (d) Cancellation of the agreement; or (e) Cancellation of agreement followed with compensation.

\section{REFERENCES}

Basuki, Sulistyo. (2010). Metode Penelitian. Jakarta: Penaku.

Dewi, Alexandra Indriyanti. (2008). Etika dan Hukum Kesehatan. Yogyakarta: Penerbit Pustaka.

Felenditi, Dionisius. (2009). “Penegakan Otonomi Pasien Melalui Persetujuan Tindakan Medis (Informed Consent)." Jurnal Biomedik Fakultas Kedokteran Universitas Sam Ratulangi, Volume 1, Nomor 1.

Fuady, Munir. (2005). Sumpah Hippocrates (Aspek Hukum Malpraktik Dokter). Bandung: Citra Aditya Bakti.

Guwandi, J. (2006). Informed Consent \& Informed Refusal. Jakarta: Fakultas Kedokteran Universitas Indonesia.

Hanafiah, M. Jusuf, \& Amri Amir. (1999). Etika Kedokteran \& Hukum Kesehatan: Edisi 3. Jakarta: Penerbit Buku Kedokteran EGC.

Isfandyarie, Anny. (2006). Tanggung Jawab Hukum dan Sanksi bagi Dokter. Jakarta: Prestasi Pustaka.

. (2005). Malpraktek dan Resiko Medik dalam Kajian Hukum Pidana. Jakarta: Prestasi Pustaka.

Kerbala, Husein. (2000). Segi-Segi Etis dan Yuridis Informed Consent. Jakarta: Pustaka Sinar Harapan.

Koeswadji, Hermien Hadijati. (1998). Hukum Kedokteran: Studi tentang Hubungan Hukum dalam mana Dokter sebagai Salah Satu Pihak. Bandung: Citra Aditya Bakti.

Komalawati, Veronica. (1999). Peranan Informed Consent dalam Transaksi Terapeutik: Suatu Tinjauan Yuridis Persetujuan dalam Hubungan Dokter dan Pasien. Bandung: Citra Aditya Bakti.

. (1989). Hukum dan Etika dalam Praktik Dokter. Jakarta: Pustaka Sinar Harapan.

Konsil Kedokteran Indonesia. (2006). Manual Persetujuan Tindakan Kedokteran. Jakarta: Konsil Kedokteran Indonesia. 
Nasution, Bahder Johan. (2005). Hukum Kesehatan: Pertanggungjawaban Dokter. Jakarta: PT. Rineka Cipta.

Ohoiwutun, Y. A. Triana. (2009). Bunga Rampai Hukum Kedokteran, Cetakan Kedua. Malang: Banyumedia Publishing.

Pakendek, Adriana. (2010). "Informed Consent Dalam Pelayanan Kesehatan", Jurnal alIhram Universitas Madura Pamekasan, Vol. V, No. 2.

Prastowo, Andi. (2012). Metode Penelitian Kualitatif Dalam Perspektif Rancangan Penelitian. Yogyakarta: Ar-ruzzmedia.

Sacharissa, Vicia. "Tinjauan Yuridis Hak Pasien untuk Menolak Prosedur Medis atau Tindakan Tertentu Menurut Sistem Hukum Indonesia dan Amerika." Skripsi Universitas Gadjah Mada, 2018.

Subekti. (1987). Hukum Perjanjian. Cetakan XI. Jakarta: PT Intermasa 